\title{
Perlindungan Hukum Terhadap Anak Korban Tindak Pidana Kekerasan Seksual
}

\section{Syuha Maisytho Probilla, Andi Najemi, Aga Anum Prayudi}

Fakultas Hukum Universitas Jambi

Author's email correspondence: syuhamaisythoprobilla@gmail.com

\section{ABSTRAK}

Artikel ini menjelaskan 1) Anak korban WA tidak mendapatkan perlindungan hukum karena sejak awal Anak korban dinyatakan sebagai pelaku, bukan sebagai korban. Status korban sebagai pelaku, sampai putusan pengadilan menjatuhkan pidana dan korban sempat menjalani masa pidananya di LPKA. Korban baru mendapat pendampingan secara hukum setelah didampingi Penasihat Hukum post ajudikasi. 2) Kendala yang dihadapi sehingga Anak korban tidak mendapatkan perlindungan hukum dikarenakan kurangnya sensitifitas UPTD PPA dalam melihat "kekhususan" yang terdapat dalam kasus WA, dimana WA tidak hanya sebagai pelaku tetapi juga korban yang harus dipenuhi hak-haknya. Saran: Perlu dimuatnya pengaturan secara pokok mengenai UPTD PPA dalam ketentuan Undang-Undang Nomor 35 Tahun 2014 Tentang Perubahan Atas Undang-Undang Nomor 23 Tahun 2002 Tentang Perlindungan Anak sebagai bentuk penguatan eksistensi kelembagaan UPTD PPA. UPTD PPA harus lebih proaktif dan sensitif terhadap perkembangan kasus kekerasan seksual di Indonesia serta meningkatkan sarana dan prasarana yang akan mendukung pemenuhan perlindungan terhadap korban tindak pidana kekerasan seksual agar menjadi lebih optimal.
\end{abstract}

\section{ARTICLE HISTORY}

Submission: 2021-04-23

Accepted: 2021-04-25

Publish: 2021-04-26

KEYWORDS: Child

Victim, sexual violence; legal protection; crime;

\begin{abstract}
This article explains 1) Child as victim of sexual violence in the case of WA did not obtain legal protection as from the beginning the victim was declared as the perpetrator rather than as a victim. The victim was granted status as the perpetrator until the court verdict imposed a crime and the victim had served the sentence at LPKA. The victim received post-adjudication legal assistance after being accompanied by a Legal Counsel. 2) The obstacles faced so that child victims did not obtain legal protection is due to the lack of sensitivity by the UPTD PPA in understanding the "specificity" contained in the case of $W A$, where WA is not only the perpetrator but the victim as well whose rights must be fulfilled. It is necessary to include basic regulations regarding the UPTD PPA in the provisions of Act Number 35 Year 2014 on the Amendments to Act Number 23 Year 2002 on Child Protection as a form of strengthening the institutional existence of UPTD PPA. The UPTD PPA must be more proactive and sensitive to developments in cases of sexual violence in Indonesia and improve facilities and infrastructure that will support the fulfillment of protection for victims of sexual violences in order to be more optimal.
\end{abstract}

\section{A. PENDAHULUAN}

Perlindungan hukum merupakan suatu bentuk pelayanan yang wajib diberikan oleh negara, terutama pemerintah untuk memberikan rasa aman kepada setiap warga 
negara. Dalam konteks Negara Kesatuan Republik Indonesia, konstitusi telah mengatur secara tegas tentang perlindungan anak. Undang-Undang Dasar Negara Republik Indonesia Tahun 1945 Pasal 28B Ayat (2) menyatakan bahwa "Setiap anak berhak atas kelangsungan hidup, tumbuh dan berkembang serta berhak atas perlindungan dari kekerasan dan diskriminasi". Berdasarkan Undang-Undang Dasar Negara Republik Indonesia, negara bertanggung jawab atas perlindungan Hak Asasi Manusia. Sebagaimana yang tercantum pada Pasal 28I ayat (4) Undang-Undang Dasar Negara Republik Indonesia Tahun 1945 yang menyatakan: "Perlindungan, pemajuan, penegakan, dan pemenuhan hak asasi manusia adalah tanggung jawab negara, terutama pemerintah".

Mengacu pada fakta sosiologis yang terjadi saat ini, Komisi Nasional Anti Kekerasan Terhadap Perempuan (Komnas Perempuan) meluncurkan Catatan Tahunan (CATAHU) Kekerasan terhadap Perempuan di Indonesia Tahun 2019, dengan judul Korban Bersuara, Data Bicara Sahkan RUU Penghapusan Kekerasan Seksual Sebagai Wujud Komitmen Negara "yang merupakan pendokumentasian berbagai kasus kekerasan terhadap perempuan yang dilaporkan dan ditangani oleh lembaga pengadalayanan, baik yang diselenggarakan pemerintah maupun organisasi masyarakat, serta pengaduan yang langsung datang ke Komnas Perempuan"1.

Kekerasan terhadap perempuan merupakan masalah krusial dan menjadi tantangan saat ini. Banyak kasus perempuan menjadi korban karena kerentanan dan ketidakberdayaan. Bahkan kecenderungan korban masih berusia anak-anak juga semakin meningkat saat ini, baik di dalam keluarga, di lingkungan masyarakat, maupun di sekolah². Pengaduan kasus kekerasan terhadap perempuan pada tahun 2018 meningkat 14\% dari tahun sebelumnya. CATAHU Tahun 2019 merekam kasus kekerasan terhadap perempuan dan anak perempuan yang dilaporkan sepanjang tahun 2018, di mana terdapat sejumlah temuan, pola dan trend kekerasan, yaitu kekerasan di ranah privat (korban dan pelaku berada dalam relasi perkawinan, kekerabatan, atau relasi intim lainnya), pelaporan kasus Marital Rape, Incest (perkosaan oleh orang yang memiliki hubungan darah) masih cukup tinggi dilaporkan pada tahun 2018 (mencapai 1071 kasus dalam 1 tahun), pengaduan kasus kekerasan dalam pacaran ke institusi pemerintah (1750 dari 2073 kasus, didominasi kasus kekerasan seksual), kekerasan berbasis cyber yang dominan terjadi pada tahun 2018, dan kekerasan seksual di ranah publik.

Kitab Undang-Undang Hukum Pidana Indonesia, yang dijadikan acuan utama bagi kalangan praktisi hukum untuk menjaring pelaku kejahatan kekerasan seksual, mengandung kekurangan secara substansial dalam hal melindungi korban kekerasan seksual. Korban dalam sisi yuridis ini tidak mendapatkan perlindungan yang istimewa ${ }^{3}$.

1 Siaran Pers Catatan Tahunan (CATAHU) Komnas Perempuan 2019, https:// www. Komnasperempuan.go.id/read-news-siaran-pers-catatan-tahunan-catahu-komnas-perempuan2019, diakses pada 17 April 2019 pukul 19:23 WIB. hlm. 1.

2 Hafrida dan Nelli Herlina, "Analisis Yuridis Perlindungan Hukum Anak Korban Kekerasan Seksual di Wilayah Hukum Kota Jambi", Jurnal Ilmu Hukum, Volume 7, Nomor 2, Oktober, 2016 FAKULTAS HUKUM UNIVERSITAS JAMBI, hlm. 99. https:// repository. unja.ac.id /619 /1/6 .\%20Nelli\%20Herlina\%20\%26\%20Hafrida.pdf

3 Abdul Wahid dan Muhammad Irfan, Perlindungan Terhadap Korban Kekerasan Seksual (Advokasi atas Hak Asasi Perempuan), Refika Aditama, Bandung, 2011, hlm. 109. 
Kitab Undang-Undang Hukum Acara Pidana (KUHAP) Indonesia, juga tidak mengakomodir hak korban kekerasan seksual. Di dalam KUHAP lebih banyak diatur mengenai tersangka dari pada mengenai korban sehingga kedudukan korban dalam KUHAP belum optimal ${ }^{4}$. Berkaca pada hal tersebut, dalam konteks perlindungan terhadap perempuan dan anak, hadirnya Undang-Undang Nomor 35 Tahun 2014 Tentang Perubahan Atas Undang-Undang Nomor 23 Tahun 2002 Tentang Perlindungan Anak, merupakan harapan baru bagi anak korban kekerasan seksual untuk mendapatkan perlindungan hukum atas apa yang dialaminya.

Perlindungan korban menjadi perhatian utama dalam peradilan pidana melalui suatu pendekatan yang disebut sebagai Keadilan Restoratif, dalam hal ini berdasarkan pendapat Hafrida, beliau menyatakan bahwa:

Keadilan restoratif adalah merupakan pendekatan dalam Penyelesaian suatu perkara pidana melalui keterlibatan banyak pihak seperti pihak pelaku/keluarganya, korban/keluarganya dan kelompok masyarakat terkait. Dengan demikian keadilan restoratif memiliki tujuan baik yang ingin dicapai bagi korban tindak pidana, bukan semata-mata bertumpu pada kebaikan dan kepentingan pelaku tindak pidana semata karena keadilan restoratif bersumber dari akar nilai yang diusung oleh nilai-nilai tradisional dalam masyarakat tradisional. ${ }^{5}$

Perlindungan hukum terhadap anak korban tindak pidana kekerasan seksual telah diatur dalam Pasal 59 Undang-Undang Nomor 35 Tahun 2014 Tentang Perubahan Atas Undang-Undang Nomor 23 Tahun 2002 Tentang Perlindungan Anak yang menentukan:

(1) Pemerintah, Pemerintah Daerah, dan lembaga Negara lainnya berkewajiban dan bertanggung jawab untuk memberikan Perlindungan Khusus kepada Anak.

(2) Perlindungan Khusus kepada Anak sebagaimana dimaksud pada ayat (1) diberikan kepada: a. Anak dalam situasi darurat; b. Anak yang berhadapan dengan hukum; c. Anak dari kelompok minoritas dan terisolasi; d. Anak yang dieksploitasi secara ekonomi dan/atau seksual; e. Anak yang menjadi korban penyalahgunaan narkotik, alkohol, psikotropika, dan zat adiktif lainnya; f. Anak yang menjadi korban pornografi; g. Anak dengan HIV/AIDS; h. Anak korban penculikan, penjualan, dan/atau perdagangan; i. Anak korban kekerasan fisik dan/atau psikis; j. Anak korban kejahatan seksual; k. Anak korban jaringan terorisme; l. Anak Penyandang Disabilitas; $\mathrm{m}$. Anak korban perlakuan salah dan penelantaran; n. Anak dengan perilaku sosial ; o. Anak yang menjadi korban stigmatisasi dari pelabelan terkait dengan kondisi Orang Tuanya.

Pasal 59A menyatakan bahwa Perlindungan Khusus bagi Anak sebagaimana dimaksud dalam Pasal 59 ayat (1) dilakukan melalui upaya:

\footnotetext{
4 Siswanto Sunarso, Viktimologi dalam Sistem Peradilan Pidana, Sinar Grafika, Jakarta, 2012, hlm. 49.

5 Hafrida, H., \& Helmi, "Perlindungan Korban melalui Kompensasi Dalam Peradilan Pidana Anak", Jurnal Bina Mulia Hukum, Edisi 5 Cet. Ke-1, 2020, hlm. 119-136. https:// doi.org/ 10.23920/ jbmh.v5i1.16.
} 
a. penanganan yang cepat, termasuk pengobatan dan/atau rehabilitasi secara fisik, psikis, dan sosial, serta pencegahan penyakit dan gangguan kesehatan lainnya;

b. pendampingan psikosial pada saat pengobatan sampai pemulihan;

c. pemberian bantuan sosial bagi Anak yang berasal dari Keluarga tidak mampu; dan

d. pemberian perlindungan dan pendampingan pada setiap proses peradilan.

Adapun pada Pasal 69A mengatur mengenai Perlindungan Khusus bagi Anak korban kejahatan seksual dilakukan melalui upaya:

a. edukasi tentang kesehatan reproduksi, nilai agama, dan nilai kesusilaan;

b. rehabilitasi sosial;

c. pendampingan psikososial pada saat pengobatan sampai pemulihan; dan

d. pemberian perlindungan dan pendampingan pada setiap tingkat pemeriksaan mulai dari penyidikan, penuntutan, sampai dengan pemeriksaan di sidang pengadilan.

Peraturan Menteri Pemberdayaan Perempuan dan Perlindungan Anak Republik Indonesia Nomor 6 Tahun 2015 Tentang Sistem Pemberdayaan Perempuan dan Anak dalam Pasal 11 mengamanatkan dibentuknya Pusat Perlindungan Terpadu Pemberdayaan Perempuan dan Anak (P2TP2A) dalam rangka mengefektifkan perlindungan pemberdayaan perempuan dan anak, baik di pusat ataupun daerah secara komprehensif, inklusif, dan integratif. "Namun, terhitung tanggal 1 Januari 2019 layanan Pusat Pelayanan Terpadu Pemberdayaan Perempuan dan Anak (P2TP2A) menjadi Unit Pelaksana Teknis Daerah Perlindungan Perempuan dan Anak (UPTDPPA)"6. Ketentuan lebih lanjut mengenai Unit Pelaksana Teknis Daerah Perlindungan Perempuan dan Anak (UPTD PPA), diatur melalui Peraturan Menteri Pemberdayaan Perempuan dan Perlindungan Anak Nomor 4 Tahun 2018 Tentang Pedoman Pembentukan UPTD PPA. Tercatat hingga September 2019, UPTD PPA terbentuk di 20 Provinsi dan 36 Kabupaten/Kota dengan jumlah 130 unit7. Termasuk UPTD PPA Provinsi Jambi yang diatur lebih lanjut melalui Peraturan Gubernur Provinsi Jambi Nomor 61 Tahun 2018.

Pada tahun 2018, Provinsi Jambi sempat digemparkan dengan adanya sebuah kasus kekerasan seksual yang di mana Anak korban inisial WA (15 Tahun), yang seharusnya dilindungi Negara, namun ironinya, korban divonis dan dinyatakan bersalah melakukan tindak pidana aborsi oleh hakim melalui amar Putusan Nomor 4/Pidsus-anak/2019/PN Mbn dan Nomor 6/Pidsus-anak/2018/PN Mbn'. Sebagaimana amanat pada Pasal 59 Ayat (1) Undang-Undang Nomor 35 Tahun 2014 Tentang Perubahan Atas Undang-Undang Nomor 23 Tahun 2002 Tentang Perlindungan Anak bahwa Anak korban seharusnya dilindungi oleh UPTD PPA Provinsi Jambi. Begitu kompleks perlindungan khusus yang dinyatakan dalam UU tersebut.

6 “Sejak 1 Januari 2019, P2TP2A Menjadi UPTD-PPA". https://www.inibalikpapan.com/sejak-1januari-2019-p2tp2a-menjadi-uptd-ppa/, diakses pada 21 Juli 2020 Pukul 13:48 WIB.

7 "Bentuk UPTD PPA, Negara Tingkatkan Layanan Bagi Korban Kekerasan". https:// www. kemenpppa. go.id/index. php/page/read/29/2352/bentuk-uptd-ppa-negara-tingkatkan-layananbagi-korban-kekerasan, diakses pada 21 Juli 2020 Pukul 13:48 WIB.

8 Media Indonesia. https:// mediaindonesia.com /read/ detail/ 176523-putusan-pidana-korbanperkosaan-di-jambi-disoal, diakses pada 29 Februari 2019, pukul 16:07 WIB. 
Namun, tidak demikian dengan apa yang didapatkan Anak korban WA. Berdasarkan hasil wawancara dengan Staff UPTD PPA Provinsi Jambi menyatakan "bahwa Anak korban WA tidak bisa diberi perlindungan sebab statusnya sebagai pelaku" 9 . Padahal ia juga sebagai korban. Dalam Pasal 59 ayat (1) dinyatakan pula hak anak korban untuk dilindungi khusus oleh pemerintah daerah, dalam hal ini UPTD PPA Provinsi Jambi. Sementara yang memberikan perlindungan justru lembaga lain di luar ketentuan UU ini, yang dalam hal ini LPSK. "Kasus ini tercatat sebagai kasus pertama di Provinsi Jambi yang mendapatkan perlindungan hukum oleh Lembaga Perlindungan Saksi dan Korban (LPSK) sepanjang tahun 2017-2019"10.

Berdasarkan Pasal 59A dan Pasal 69A Undang-Undang Nomor 35 Tahun 2014 Tentang Perubahan Atas Undang-Undang Nomor 23 Tahun 2002 Tentang Perlindungan Anak, sudah sepatutnya sejak awal Anak korban berhak atas Perlindungan Khusus melalui pemberian perlindungan dan pendampingan pada setiap proses peradilan mulai dari penyidikan, penuntutan, sampai dengan pemeriksaan di sidang pengadilan. Namun Damai Idianto, SH., selaku pengacara pro bono korban, menjelaskan bahwa dalam proses hukum yang dijalani oleh Anak korban, korban baru mendapatkan perlindungan setelah adanya inisiatif dari Damai Idianto, SH., dengan mengajukan permohonan perlindungan ke LPSK. Permohonan itu diajukan pula karena pada kasus tersebut, Anak korban dianggap pelaku. "Pengadilan tidak melihat bahwa ada sebab dibalik pengguguran itu. Anak korban WA merupakan korban perbuatan kejahatan seksual yang dilakukan oleh saudara kandungnya sendiri" 11 .

Damai kemudian secara mandiri mengajukan banding putusan pidana ke Pengadilan Tinggi Provinsi Jambi. "Selanjutnya, adapun pengajuan banding tersebut, dikabulkan Pengadilan Tinggi Provinsi Jambi. Dengan demikian, Anak korban WA dinyatakan bebas walaupun Anak korban sempat menjalani kurungan di Lembaga Pembinaan Khusus Anak (LPKA) selama tiga bulan"12.

Berdasarkan kronologi kasus tersebut, Undang-Undang Nomor 35 Tahun 2014 Tentang Perubahan Atas Undang-Undang Nomor 23 Tahun 2002 Tentang Perlindungan Anak tidak terlaksana sebagaimana mestinya untuk mengakomodir hak Anak korban. Seharusnya sejak awal Anak korban diberi perlindungan dan pendampingan pada setiap proses peradilan mulai dari penyidikan, penuntutan, sampai dengan pemeriksaan di sidang pengadilan. Anak Korban baru mendapat perlindungan setelah menderita terlebih dahulu. Sepatutnya, Undang-Undang Nomor 35 Tahun 2014 Tentang Perubahan Atas Undang-Undang Nomor 23 Tahun 2002 Tentang Perlindungan Anak ini hadir guna menjamin perlindungan untuk Anak korban WA, namun disayangkan dalam implementasinya Undang-Undang ini, tidak dijalankan sebagaimana mestinya. Oleh karena itu, diperlukan penyikapan yang cepat dan tepat dari negara, sehingga akibat tindak pidana kekerasan seksual yang dialami korban dapat diminimalkan dan dapat diupayakan pemulihan yang komprehensif bagi korban semaksimal mungkin.

Tujuan dalam penelitian ini adalah untuk mengetahui mengapa Anak korban tindak pidana kekerasan seksual pada kasus WA, tidak mendapatkan perlindungan

\footnotetext{
9 Wawancara dengan Freddie, Staff UPTD PPA Provinsi Jambi, Rabu 11 Desember 2019.

10 Wawancara dengan Freddie, Staff UPTD PPA Provinsi Jambi.

11 Wawancara dengan Damai Idianto, Penasihat Hukum Korban, Kamis, 19 Desember 2019.

12 Wawancara dengan Damai Idianto, Penasihat Hukum Korban.
} 
hukum berdasarkan Undang-Undang Nomor 35 Tahun 2014 Tentang Perubahan Atas Undang-Undang Nomor 23 Tahun 2002 Tentang Perlindungan Anak di wilayah hukum Provinsi Jambi dan untuk mengetahui kendala yang dihadapi sehingga perlindungan hukum terhadap Anak korban tindak pidana kekerasan seksual pada kasus WA tidak diberikan berdasarkan Undang-Undang Nomor 35 Tahun 2014 Tentang Perubahan Atas Undang-Undang Nomor 23 Tahun 2002 Tentang Perlindungan Anak di Wilayah Hukum Provinsi Jambi.

Dalam penulisan ini, yang menjadi lokasi penelitian untuk pengambilan data yang dipilih oleh penulis adalah Unit Perlindungan Terpadu Daerah Perlindungan Perempuan dan Anak Provinsi Jambi, Balai Rehabilitasi Sosial Anak Alyatama, dan LBH Pena Keadilan Jambi.

\section{B. METODE PENELITIAN}

Adapun metode penelitian yang dilakukan dalam penelitian ini adalah hukum empiris. Penelitian ilmu hukum empiris bertujuan untuk mengetahui sejauhmana bekerjanya hukum di dalam masyarakat. Penelitian ilmu hukum empiris sebagai hasil interaksi antara ilmu hukum dengan disiplin ilmu-ilmu lainnya ${ }^{13}$. Dalam penelitian ini, penulis menggunakan metode pengumpulan data Interview atau wawancara yang dilakukan secara langsung kepada Kepala Seksi Asesmen dan Advokasi Sosial Balai Rehabilitasi Sosial Anak Memerlukan Perlindungan Khusus (BRSAMPK) Alyatama Jambi, Staff Unit Perlindungan Terpadu Daerah Perlindungan Perempuan dan Anak Provinsi Jambi, dan penasihat hukum korban menggunakan pedoman wawancara.

Dalam penulisan ini, penulis menggambarkan penelitian deskriptif, yaitu memberikan suatu gambaran yang rinci tentang Perlindungan Hukum terhadap Korban Tindak Pidana Kekerasan Seksual di Wilayah Hukum Provinsi Jambi. Penulis menggunakan teknik purposive sampling ${ }^{14}$, yaitu menentukan terlebih dahulu kriteria responden yang akan diwawancarai, yang menjadi responden memahami, mengetahui bentuk perlindungan hukum bagi korban tindak pidana kekerasan seksual dan responden haruslah duduk dalam suatu instansi yang mempunyai hubungan dengan masalah perlindungan. Jumlah sampel yang dibutuhkan dalam penelitian ini adalah sebagai berikut:

a. Satu orang Staff Unit Perlindungan Terpadu Daerah Perlindungan Perempuan dan Anak Provinsi Jambi;

b. Satu orang Kepala Seksi Asesmen dan Advokasi Sosial Balai Rehabilitasi Sosial Anak Memerlukan Perlindungan Khusus (BRSAMPK) Alyatama Jambi;

Kemudian, khusus terhadap korban tindak pidana kekerasan seksual, penulis memberikan kesempatan kepada penasihat hukum korban untuk dijadikan sampel dalam penelitian ini dikarenakan tidak memungkinnya korban untuk dijadikan responden secara langsung mengingat pendampingan dan bantuan hukum yang telah diberikan kepada korban guna menghindari rasa trauma korban muncul kembali. Sehingga responden dalam penulisan ini adalah penasihat hukum korban tindak pidana kekerasan seksual, yakni Damai.

13 Bahder Johan Nasution, Metode Penelitian Ilmu Hukum, Cet. 2, Mandar Maju, Bandung, 2016, hlm. 123.

14 Ibid., hlm. 159. 


\section{PEMBAHASAN}

\section{Perlindungan Hukum Terhadap Korban Tindak Pidana Kekerasan Seksual}

Pusat Pelayanan Terpadu Pemberdayaan Perempuan dan Anak, yang selanjutnya disebut P2TP2A adalah pusat pelayanan yang terintegrasi dalam upaya pemberdayaan perempuan di berbagai bidang pembangunan, serta perlindungan perempuan dan anak dari berbagai jenis diskriminasi dan tindak kekerasan, termasuk perdagangan orang, yang dibentuk oleh pemerintah atau berbasis masyarakat, dan dapat berupa: pusat rujukan, pusat konsultasi usaha, pusat konsultasi kesehatan reproduksi, pusat konsultasi hukum, pusat krisis terpadu (PKT), pusat pelayanan terpadu (PPT), pusat pemulihan trauma (trauma center), pusat penanganan krisis perempuan (women crisis center), pusat pelatihan, pusat informasi ilmu pengetahuan dan teknologi (PIPTEK), rumah aman (shelter), rumah singgah, atau bentuk lainnya ${ }^{15}$.

Peraturan Menteri Pemberdayaan Perempuan dan Perlindungan Anak Republik Indonesia Nomor 6 Tahun 2015 Tentang Sistem Pemberdayaan Perempuan dan Anak dalam Pasal 11 mengamanatkan dibentuknya Pusat Perlindungan Terpadu Pemberdayaan Perempuan dan Anak (P2TP2A) dalam rangka mengefektifkan perlindungan pemberdayaan perempuan dan anak, baik di pusat ataupun daerah secara komprehensif, inklusif, dan integratif. "Namun, terhitung Tanggal 1 Januari 2019 layanan Pusat Pelayanan Terpadu Pemberdayaan Perempuan dan Anak (P2TP2A) menjadi Unit Pelaksana Teknis Daerah Perlindungan Perempuan dan Anak (UPTDPPA)"16.

Ketentuan lebih lanjut mengenai Unit Pelaksana Teknis Daerah Perlindungan Perempuan dan Anak (UPTD PPA), diatur melalui Peraturan Menteri Pemberdayaan Perempuan dan Perlindungan Anak Nomor 4 Tahun 2018 Tentang Pedoman Pembentukan UPTD PPA. Tercatat hingga September 2019, UPTD PPA terbentuk di 20 Provinsi dan 36 Kabupaten/Kota dengan jumlah 130 unit ${ }^{17}$.

Termasuk UPTD PPA Provinsi Jambi yang diatur lebih lanjut melalui Peraturan Gubernur Provinsi Jambi Nomor 61 Tahun 2018.

Unit Pelaksana Teknis Daerah Perlindungan Perempuan dan Anak (UPTD PPA) memiliki tugas untuk melaksanakan kegiatan teknis operasional di wilayah kerjanya dalam memberikan layanan bagi perempuan dan anak yang mengalami masalah kekerasan, diskriminasi, perlindungan khusus, dan masalah lainnya.

UPTD PPA berkedudukan di bawah dan bertanggung jawab kepada Kepala Dinas yang menyelenggarakan urusan pemerintahan di bidang pemberdayaan perempuan dan perlindungan anak di tingkat daerah provinsi dan derah kabupaten/kota. Fungsi UPTD PPA adalah menyelenggarakan layanan :

a. pengaduan masyarakat;

b. penjangkauan korban;

15 Kementerian Pemberdayaan Perlindungan Perempuan dan Anak Republik Indonesia, Glosary Perlindungan Perempuan, https://www.kemenpppa.go.id/index.php/page/view/21 diakses pada tanggal 15 April 2019 pukul 20:56 WIB.

16 "Sejak 1 Januari 2019, P2TP2A Menjadi UPTD-PPA". https://www.inibalikpapan.com/sejak-1januari-2019-p2tp2a-menjadi-uptd-ppa/, diakses pada tanggal 21 Juli 2020 Pukul 13:48 WIB.

17 "Bentuk UPTD PPA, Negara Tingkatkan Layanan Bagi Korban Kekerasan". https://www.kemenpppa.go.id/index.php/page/read/29/2352/bentuk-uptd-ppa-negaratingkatkan-layanan-bagi-korban-kekerasan, diakses pada tanggal 21 Juli 2020 Pukul 13:48 WIB. 
c. pengelolaan kasus;

d. penampungan sementara;

e. mediasi; dan

f. pendampingan korban.

UPTD PPA merupakan UPTD generik yang dalam prinsip pembentukannya berdasar pada Peraturan Menteri Dalam Negeri Nomor 12 Tahun 2017 tentang Pedoman Pembentukan dan Klasifikasi Cabang Dinas dan Unit Pelaksana Teknis Daerah. Kebijakan pembentukan UPTD PPA sebagai penyedia layanan perlindungan bagi perempuan dan anak telah ditetapkan melalui Peraturan Menteri Pemberdayaan Perempuan dan Perlindungan Anak Nomor 4 Tahun 2018 Tentang Pedoman Pembentukan UPTD PPA ${ }^{18}$.

Posisi korban dalam suatu tindak pidana mengandung masalah hukum yang tidak selalu mudah dipecahkan, oleh karenanya seorang korban tindak pidana dapat dimungkinkan mengalami korban berikutnya (secondary victimization), disebabkan adanya penolakan secara sistematis oleh sistem peradilan pidana. Hukum memiliki andil dalam konstruksi proses viktimisasi dengan orientasi hukum pidana yang sangat terbatas dan tradisional, persoalan korban menjadi persoalan sepele dan tidak diperhatikan ${ }^{19}$.

Oleh karena itu, keberadaan UPTD PPA, dalam sistem peradilan pidana ini diharapkan dapat mengatasi kelemahan penegakan hukum di Indonesia, terutama ditandai dengan pentingnya hubungan antara sub-sistem dengan sub-sistem yang lain dalam sistem peradilan pidana, serta hubungannya dengan UPTD PPA sebagai lembaga yang memberikan perlindungan terhadap keberadaan korban perempuan dan anak.

Namun, sayangnya harapan tersebut tidak terimplementasi dengan baik. Hal ini dilihat dari apa yang dialami oleh korban WA (15), seorang korban perkosaan yang melalui Putusan Nomor 5/Pid.Sus.Anak/2018/PN Mbn dinyatakan bersalah melakukan tindak pidana aborsi dan dijatuhi pidana penjara selama 6 bulan. Sungguh ironi, padahal permasalahannya adalah kehamilan yang dialami oleh WA merupakan hasil dari perkosaan yang dilakukan oleh abang kandungnya sendiri. Menurut Institute Criminal Justice Reform (ICJR), berdasarkan Putusan Nomor 5/Pid.Sus.Anak/2018/PN Mbn, pengadilan hanya memfokuskan pada tindak pidana aborsinya saja, dan tidak menyelidiki secara mendalam dan hati-hati terkait dengan penyebab dilakukannya tindak pidana aborsi tersebut ${ }^{20}$.

In the case of WA, the country should be present from the start that WA is a child who is a victim of rape that must be protected. The state (police) can use discretionary measures not to continue the case of child victims of rape in the legal sphere. Police authorities are given the law to act in special situations in accordance with the judgment and conscience of the agency or the official itself. This act of discretion must be seen as an attempt to find a solution that does not cause new problems, including injustice. Unfortunately this discretionary action was not used by investigators in

18 https://www.kemenpppa.go.id/index.php/page/view/127, diakses pada 21 Juli 2020 Pukul 14:00 WIB.

19 Agus Takariawan, Perlindungan Saksi Dan Korban Cetakan ke-l, Pustaka Reka Cipta, Bandung, 2016, hlm. 15.

20 Anggara et al., "Jangan Hukum Korban Perkosaan! Amicus Curae (Sahabat Pengadilan) Dalam Perkara 6/PID.SUS/-Anak/2018/JMB di Pengadilan Tinggi Jambi", Majalah Institute for Criminal Justice Reform, 2018, hlm. 13. 
handling this case, so the case was delegated to the District Prosecutor's Office Muaro Bulian ${ }^{21}$.

Berdasarkan kutipan jurnal di atas, kehadiran Negara berdasarkan UUPA absen, dalam hal ini UPTD PPA Provinsi Jambi. Bentuk perlindungan hukum terhadap Anak korban kekerasan seksual tercantum pada Pasal 59A dan Pasal 69A yang menyatakan bahwa Anak korban berhak atas Perlindungan Khusus melalui pemberian perlindungan dan pendampingan pada setiap proses peradilan pidana, mulai dari penyidikan, penuntutan, sampai dengan pemeriksaan di sidang pengadilan.

Berdasarkan wawancara penulis dengan Kepala Seksi Asesmen dan Advokasi Sosial Balai Rehabilitasi Sosial Anak Memerlukan Perlindungan Khusus (BRSAMPK) Alyatama Jambi, Bapak Lifyarman mengatakan bahwa korban mendapat bantuan dari LPSK berdasarkan kerjasama dengan lembaganya ${ }^{22}$. Bantuan yang diberikan berupa bantuan rehabilitasi Psikis dan Psikologis korban. Lebih lanjut, Bapak Lifyarman mengatakan bahwa lembaga tersebut juga memberi pelayanan berupa kebutuhankebutuhan dasar korban selama dalam masa rehabilitasi, seperti kebutuhan sekolah dan tempat, sebab korban harus dikembalikan ke keluarga atau dirujuk ke lembaga lain karna dia harus melanjutkan sekolah.

Mengenai LPSK, ia mengatakan bahwa LPSK memfasilitasi WA terkait sekolah yang diinginkan, pekerjaan, serta keahlian yang diinginkan korban. Yang mana untuk seluruh biaya akan ditanggung LPSK. Kemudian, ia menjelaskan yang menjangkau korban awalnya ialah P2TP2A Provinsi Jambi.

Karena Waktu itu WA kan berada di LPA di Sungai Buluh. Ia sebagai korban bukan sebagai pelaku. Maka, tidak layak ditempatkan di sana karena tidak sesuai usianya. Direktorat anak menghubungi alyatama bahwa ia harus masuk ke lembaga kita yaitu Rumah Perlindungan Sosial Anak utk korban tindak kekerasan, pelecehan seksual, dan trafficking bagi anak. Setelah kita menjangkau dn menjemput oleh P2TP2A Provinsi Jambi dan penasihat hukum maka si WA mulai dibina dan dipantau setiap hari perkembangannya, sehingga pada akhirnya harus kita kembalikan dan dirujuk ke lembaga lain karena ada perubahan nomenklatur lembaga kita pada waktu itu. Karena si WA sudah di sini, saya baru dua kali ditemui LPSK setelah korban sampai di sini. Di sini kita lihat perkembangan psikis, kebutuhan dasar, kita ketemukan dengan psikolog, kalau sakit kita hubungi perawat untuk ke sini, kalau sakit parah kami rujuk ke RS. Kesehatannya terus kami pantau. Jika kepolisian atau penasihat hukum mewawancarai WA maka kami harus mendampingi agar jangan sampai pertanyaan-pertanyaan yang akan ditanya tidak kelewat batas. Kami membatasi pertanyaan -pertanyaan berat. Kami menjaga psikis WA ${ }^{23}$.

Dengan demikian, hak korban justru terpenuhi berdasarkan Pasal 6 ayat (1) Undang-Undang LPSK, melalui kerjasama dengan Balai Rehabilitasi Sosial Anak Memerlukan Perlindungan Khusus (BRSAMPK) Alyatama Jambi. Hal ini sejalan dengan

\footnotetext{
${ }^{21}$ Elita Rahmi dan Elly Sudarti, "State Protection Upon Adolescent Victim of Incest Rape Through Gender Lens", Diponegoro Law Review, Volume 04, Number 01. April 2019, hlm. 98. Diakses dari https://ejournal.undip.ac.id/index.php/dlr/article/view/24133.

22 Wawancara dengan Lifyarman, Kepala Seksi Asesmen dan Advokasi Sosial Balai Rehabilitasi Sosial Anak Memerlukan Perlindungan Khusus (BRSAMPK) Alyatama Jambi, Kamis, 12 Desember 2019.

23 Wawancara dengan Lifyarman, Kepala Seksi Asesmen dan Advokasi Sosial Balai Rehabilitasi Sosial Anak Memerlukan Perlindungan Khusus (BRSAMPK) Alyatama Jambi.
} 
wawancara penulis dengan penasihat hukum korban, yakni Damai Idianto, S.H., yang mengajukan permohonan perlindungan kepada LPSK. Setelah LPSK meneliti dan menganggap layak permohonan tersebut, maka diinfokan kepada pemohon bahwa pemohon layak diberi perlindungan dan pihak LPSK menginformasikan hak yang didapat korban kepada korban Damai Idianto, S.H., yakni hak-hak prosedural berdasarkan Pasal 6 ayat (1) Undang-Undang ini yang menyatakan bahwa korban berhak mendapatkan bantuan medis dan bantuan rehabilitasi psikososial dan psikologis ${ }^{24}$.

"Lalu, LPSK turun ke Lapangan. Terkait kasus WA, cukup rumit. Karena diancam pidana aborsi (pasal 346 KUHP). Saya memandang bahwa WA, korban perbuatan tindakan asusila yaitu seksual tadi dari saudara kandung sendiri. Maka, saya banding putusan pidana ke Pengadilan Tinggi. Lalu, dikabulkan Pengadilan Tinggi dengan dasar Undang-Undang Kesehatan. Maka WA bebas. Adapun permohonan perlindungan diajukan sebelum putusan banding dikabulkan. Namun belum mendapat kabar karena mereka punya assessment. Akhirnya disetujui, berbarengan dengan dapat penangguhan tahanan bagi WN untuk lepas dari Lapas Anak. Lalu diinfokan ke LPSK, baru diajukan ke LPSK. Jadi, saya mendampingi korban setelah dari kepolisian. Permohonan disetujui dan direalisasikan LPSK dan korban ditempatkan di Alyatama. Namun saya lupa tanggal diajukan dan disetujui permohonan sebab semua berkas sudah tercecer dikarenakan kantor saya pindah. Terkait Pasal 6 UU LPSK, WA dapat psikososial dan psikologis. Perlindungan kepada WA hanya ketika saya mulai mendampingi. Pada waktu penyelidikan, penyidikan, penetapan sebagai tersangka, pelimpahan ke Kejaksaan, bukan saya pengacaranya. Setau saya WA mulai mendapat perlindungan semenjak saya mengajukan permohonan perlindungan ke LPSK. WA ini kasihan sekali ya. Paradigma masyarakat tentang WA ini tidak berpihak kepada korban. Sehingga WA tidak boleh kembali lagi ke daerah awal. Harusnya masyarakat menerima WA". ${ }^{25}$

Berdasarkan wawancara yang penulis lakukan tersebut perlindungan hukum yang didapat korban WA, tidak mendapat perlindungan lain selain apa yang tercantum pada Pasal 6 ayat (1) UU LPSK. Padahal seharusnya WA mendapatkan hak yang dinyatakan pada Pasal 59A dan Pasal 69A Undang-Undang Nomor 35 Tahun 2014 Tentang Perubahan Atas Undang-Undang Nomor 23 Tahun 2002 Tentang Perlindungan Anak, yakni Anak korban WA sejak awal berhak atas Perlindungan Khusus melalui pemberian perlindungan dan pendampingan pada setiap proses peradilan pidana, mulai dari penyidikan, penuntutan, sampai dengan pemeriksaan di sidang pengadilan yang mana akan memberikan bantuan dalam memproses kasus WA ini.

Anak korban WA tidak dapat perlindungan sejak tahap penyelidikan, penyidikan, penuntutan, dan pemeriksaan di Pengadilan Negeri. Masa persidangan sangat singkat, tidak ada agenda sidang yang menjamin hak terpidana terlindungi. Proses pemeriksaan perkara Anak Korban perkosaan ini hanya dilakukan dengan agenda sidang sebagai

24 Wawancara dengan Damai Idianto, Penasihat Hukum Korban, Kamis, 19 Desember 2019.

25 Wawancara dengan Damai Idianto, Penasihat Hukum Korban. 
berikut, hal ini dapat dibuktikan berdasarkan informasi yang didapat dari Sistem Informasi Penelurusan Perkara Pengadilan Negeri Muara Bulian²6.

Tabel

Jadwal Sidang Perkara Anak Korban Perkosaan di Pengadilan Negeri Muara Bulian

\begin{tabular}{|c|c|c|c|}
\hline Tanggal Sidang & Jam & Agenda & Ruangan \\
\hline Senin, 09 Jul. 2018 & $13: 40: 00 \mathrm{~s} / \mathrm{d}$ 15:45:00 & $\begin{array}{l}\text { Dakwaan, } \\
\text { Pemeriksaan } \\
\text { Saksi }\end{array}$ & $\begin{array}{l}\text { Ruang Sidang Cakra } \\
\text { (Semua pihak) }\end{array}$ \\
\hline Rabu, 11 Jul. 2018 & $11: 45: 00 \mathrm{~s} / \mathrm{d}$ 13:30:00 & $\begin{array}{l}\text { Pemeriksaan } \\
\text { Saksi dan Anak }\end{array}$ & $\begin{array}{l}\text { Ruang Sidang Anak } \\
\text { (semua pihak) }\end{array}$ \\
\hline Kamis, 12 Jul. 2018 & $10: 50: 00 \mathrm{~s} / \mathrm{d} 10: 55: 00$ & $\begin{array}{l}\text { Tuntutan } \\
\text { Penuntut Umum }\end{array}$ & $\begin{array}{l}\text { Ruang Sidang Anak } \\
\text { (semua pihak) }\end{array}$ \\
\hline Rabu, 18 Jul. 2018 & $16: 00: 00 \mathrm{~s} / \mathrm{d} 16: 30: 00$ & $\begin{array}{l}\text { Tuntutan } \\
\text { Penuntut Umum, } \\
\text { dilanjutkan } \\
\text { dengan } \\
\text { pembelaan } \\
\text { Penasihat Hukum } \\
\text { Anak }\end{array}$ & $\begin{array}{l}\text { Ruang Sidang Anak } \\
\text { (semua pihak) }\end{array}$ \\
\hline Kamis, 19 Jul. 2018 & $14: 35: 00 \mathrm{~s} / \mathrm{d} 15: 00: 00$ & $\begin{array}{l}\text { Pembacaan } \\
\text { Putusan }\end{array}$ & $\begin{array}{l}\text { Ruang Sidang Anak } \\
\text { (semua pihak) }\end{array}$ \\
\hline
\end{tabular}

Sumber: Sistem Informasi Penelurusan Perkara Pengadilan Negeri Muara Bulian

Artinya dengan demikian, korban baru mendapatkan bantuan hukum pada tanggal yang sama dengan hari pertama sidang, sehingga selama proses pemeriksaan sebelum persidangan tidak ada bantuan hukum yang diberikan kepada korban. Padahal berdasarkan Pasal 59A dan Pasal 69A Undang-Undang Nomor 35 Tahun 2014 Tentang Perubahan Atas Undang-Undang Nomor 23 Tahun 2002 Tentang Perlindungan Anak, Anak korban WA sejak awal berhak atas Perlindungan Khusus melalui pemberian perlindungan dan pendampingan pada setiap proses peradilan pidana, mulai dari penyidikan, penuntutan, sampai dengan pemeriksaan di sidang pengadilan.

Dalam proses pemeriksaan perkara, tidak ada bantuan hukum yang efektif dan kredibel untuk korban. Dalam putusan, dinyatakan anak Korban perkosaan mendapatkan bantuan hukum per tanggal 9 Juli 2018 berdasarkan Surat Penetapan Nomor 5/Pen.Pid.Sus-Anak/2018/Pn Mbn, yang didampingi oleh Damai Idianto, S.H. Sedangkan, proses pemeriksaan telah berlangsung sejak 31 Mei 2018, dan

26 http: // sipp. pn -muarabulian. go.id/ index.php/ detil_perkara\#, diakses pada Kamis, 19 Desember 2019. 
pemeriksaan di pengadilan sidang pertama dilaksanakan pada 9 Juli $2018^{27}$. Sehingga hal ini menunjukkan bahwa tidak ada agenda sidang pembelaan terdakwa.

Hakikat diberikannya hak untuk diberi perlindungan dan pendampingan bagi Anak korban yang berdasarkan Putusan Nomor 5/Pid.Sus.Anak/2018/PN Mbn sebagai terdakwa adalah untuk memastikan bahwa terdakwa dapat mengajukan pembelaan, dan penasihat hukum menjalankan tugasnya untuk kepentingan pembelaan terdakwa yang dalam hal ini adalah Anak korban perkosaan.

Bahkan perkara ini dimohonkan permohonan banding oleh Anak korban perkosaan melalui Damai Idianto, S.H., pada tanggal 27 Juli 2018 selaku penasihat hukum Anak korban. Penasihat hukum Anak korban mengajukan permohonan banding untuk menjamin adanya keadilan dalam kasus Anak korban WA, dalam hal ini kepentingan pembelaan yang dibutuhkan untuk melepaskan jerat pemidanaan kepada korban perkosaan yang didakwa melakukan aborsi terhadap kandungan yang dideritanya akibat perkosaan, sehingga korban WA dinyatakan bebas setelah putusan banding dikabulkan oleh Pengadilan Tinggi Jambi pada tanggal 27 Agustus 2018, walaupun korban sempat menjalani kurungan di Lembaga Pembinaan Khusus Anak (LPKA) selama tiga bulan ${ }^{28}$.

Dengan demikian, amanat Undang-Undang Nomor 35 Tahun 2014 Tentang Perubahan Atas Undang-Undang Nomor 23 Tahun 2002 Tentang Perlindungan Anak belum optimal, dalam hal ini memberikan hak kepada Anak korban sebagaimana yang tercantum pada Pasal 59A dan Pasal 69A Undang-Undang Nomor 35 Tahun 2014 Tentang Perubahan Atas Undang-Undang Nomor 23 Tahun 2002 Tentang Perlindungan Anak, yakni Anak korban WA berhak atas Perlindungan Khusus melalui pemberian perlindungan dan pendampingan pada setiap proses peradilan pidana, mulai dari penyidikan, penuntutan, sampai dengan pemeriksaan di sidang pengadilan.

\section{Kendala yang Dihadapi Sehingga Korban Tindak Pidana Kekerasan Seksual Tidak Mendapatkan Perlindungan}

Kasus tindak pidana kekerasan seksual yang dialami oleh korban WA ini, membuka mata semua pihak bahwa korban kekerasan seksual memerlukan perlindungan yang tidak hanya perlindungan fisik namun juga perlindungan dari hukum, yang menyebabkan mereka dijerat oleh hukum pidana.

Kendala nyata yang dihadapi korban WA ialah korban tidak mendapatkan perlindungan sejak awal penyelidikan hingga berakhirnya kasus yang dialami korban WA ini. Padahal berdasarkan Pasal 59A dan Pasal 69A Undang-Undang Nomor 35 Tahun 2014 Tentang Perubahan Atas Undang-Undang Nomor 23 Tahun 2002 Tentang Perlindungan Anak, sudah sepatutnya sejak awal Anak korban WA, berhak atas Perlindungan Khusus melalui pemberian perlindungan dan pendampingan pada setiap proses peradilan mulai dari penyidikan, penuntutan, sampai dengan pemeriksaan di sidang pengadilan. Akan tetapi, pada tahap penyelidikan korban WA diselidiki sebagai pelaku karena kasus aborsi yang ia lakukan padahal aborsi tersebut merupakan akibat

27 Anggara et al., "Jangan Hukum Korban Perkosaan! Amicus Curae (Sahabat Pengadilan) Dalam Perkara 6/PID.SUS/-Anak/2018/JMB di Pengadilan Tinggi Jambi", Majalah Institute for Criminal Justice Reform, 2018, hlm. 13.

28 Ibid., hlm. 13. 
dari perkosaan yang dilakukan oleh saudara kandungnya sendiri. Dengan demikian, Undang-Undang ini tidak berkerja sebagaimana mestinya.

Dalam proses kasus korban WA ini, seharusnya disinilah peran UPTD PPA sesuai dengan ketentuannya. Bahwa UPTD PPA harus proaktif terhadap pemenuhan hak korban mengingat UPTD PPA di amanatkan secara langsung pembentukannya oleh Peraturan Menteri Pemberdayaan Perempuan dan Perlindungan Anak Republik Indonesia Nomor 6 Tahun 2015 Tentang Sistem Pemberdayaan Perempuan dan Anak.

Sepatutnya, dengan adanya payung hukum tersebut, menjadi kesadaran bersama pentingnya koordinasi terhadap perlindungan korban sebagai bagian dari penegakan sistem peradilan pidana ${ }^{29}$. Oleh karena itu, "keberadaan UPTD PPA, dalam sistem peradilan pidana ini diharapkan dapat mengatasi kelemahan penegakan hukum di Indonesia, terutama ditandai dengan pentingnya hubungan antara sub-sistem dengan sub-sistem yang lain dalam sistem peradilan pidana, serta hubungannya dengan UPTD PPA sebagai lembaga yang memberikan perlindungan terhadap keberadaan saksi dan korban"30.

Penulis melihat bahwa kurangnya sensitifitas penyedia layanan perlindungan dalam melihat "kekhususan" yang terdapat dalam kasus WA menjadi kendala utama. Apabila mencermati dengan seksama, keseluruhan kasus ini merupakan kasus berdimensi ganda, dimana pelaku adalah sekaligus korban. Namun, Anak korban WA tidak mendapat perlindungan oleh UPTD PPA karena penetapan statusnya sebagai pelaku oleh Pengadilan. Dalam kasus selayaknya kasus WA, status sebagai pelaku seharusnya tidak melunturkan pelaksanaan hak-hak yang melekat pada diri seseorang sebagai korban. Ketentuan Pasal 59A dan 69A Undang-Undang Nomor 35 Tahun 2014 Tentang Perubahan Atas Undang-Undang Nomor 23 Tahun 2002 Tentang Perlindungan Anak tidak mengecualikan korban yang berstatus sebagai pelaku dari ruang lingkup perlindungan sebagaimana dimaksud dalam UU tersebut. Secara filosofis, hal ini merupakan bagian dari penghormatan dan penjaminan terhadap hak asasi manusia.

UPTD PPA merupakan lembaga yang dibentuk secara khusus sebagai lembaga perlindungan berperspektif "korban" bagi perempuan dan anak, dan sudah selayaknya bertindak dengan perspektif yang demikian. Dengan demikian, UPTD PPA berkewajiban melakukan perlindungan, sekalipun disaat yang bersamaan yang bersangkutan juga ditetapkan sebagai tersangka. Kasus WA menunjukkan adanya gagal berfungsinya lembaga ini sesuai dengan amanat ketentuan Pasal 22 Undang-Undang Nomor 35 Tahun 2014 Tentang Perubahan Atas Undang-Undang Nomor 23 Tahun 2002 Tentang Perlindungan Anak dan Pasal 11 Peraturan Menteri Pemberdayaan Perempuan dan Perlindungan Anak Republik Indonesia Nomor 6 Tahun 2015 Tentang Sistem Pemberdayaan Perempuan dan Anak. Tidak bertindaknya UPTD PPA sesuai dengan marwahnya menyebabkan perlindungan pada korban tidak terlaksana dengan sempurna.

\section{SIMPULAN}

Bentuk perlindungan yang terdapat pada Pasal 59A dan Pasal 69A UndangUndang Nomor 35 Tahun 2014 Tentang Perubahan Atas Undang-Undang Nomor 23

29 Ibid., hlm. 13.

30 Ibid., hlm. 20. 
Tahun 2002 Tentang Perlindungan Anak yang menyatakan bahwa Anak korban tindak pidana kekerasan seksual berhak atas Perlindungan Khusus melalui pemberian perlindungan dan pendampingan pada setiap proses peradilan mulai dari penyidikan, penuntutan, sampai dengan pemeriksaan di sidang pengadilan, tidak didapat Anak korban WA karena sejak awal korban dinyatakan sebagai pelaku, bukan sebagai korban. Status korban sebagai pelaku, sampai putusan pengadilan menjatuhkan pidana dan korban sempat menjalani masa pidananya di LPKA. Korban baru mendapat pendampingan secara hukum setelah didampingi Penasihat Hukum post ajudikasi. Sedangkan kendala yang dihadapi sehingga korban tindak pidana kekerasan seksual tidak mendapatkan perlindungan hukum sebagaimana yang dimaksud pada Pasal 59A dan Pasal 69A tersebut dikarenakan kurangnya sensitifitas UPTD PPA dalam melihat "kekhususan" yang terdapat dalam kasus WA, dimana WA tidak hanya sebagai pelaku tetapi juga korban yang harus dipenuhi hak-haknya.

\section{DAFTAR PUSTAKA}

\section{Dokumen Hukum}

Republik Indonesia, Undang-Undang Dasar Negara Republik Indonesia Tahun 1945.

Republik Indonesia, Undang-Undang Tentang Hukum Acara Pidana. UU Nomor 8 Tahun 1981. LNRI Tahun 1981 Nomor 76. TLNRI Nomor 3209.

Republik Indonesia, Undang-Undang Nomor 35 Tahun 2014 Tentang Perubahan Atas Undang-Undang Nomor 23 Tahun 2002 Tentang Perlindungan Anak. LNRI Tahun 2014 Nomor 297. TLNRI Nomor 5606.

\section{Buku}

Anggara et al., "Jangan Hukum Korban Perkosaan! Amicus Curae (Sahabat Pengadilan) Dalam Perkara 6/PID.SUS/-Anak/2018/JMB di Pengadilan Tinggi Jambi", Majalah Institute for Criminal Justice Reform, 2018.

Nasution, Bahder Johan. Negara Hukum dan Hak Asasi Manusia., Bandung: Mandar Maju, Cetakan Ketiga, 2014. Kedua, 2016.

Metode Penelitian Ilmu Hukum, Bandung: Mandar Maju, Cetakan

Sunarso, Siswanto. Viktimologi dalam Sistem Peradilan Pidana. Jakarta: Sinar Grafika, 2012.

Takariawan, Agus. Perlindungan Saksi dan Korban. Bandung: Pustaka Reka Cipta, Cetakan Pertama, 2016. 
Wahid, Abdul dan Muhammad Irfan. Perlindungan Terhadap Korban Kekerasan Seksual (Advokasi atas Hak Asasi Perempuan). Bandung: Refika Aditama, 2011.

\section{Jurnal}

Hafrida dan Nelli Herlina, "Analisis Yuridis Perlindungan Hukum Anak Korban Kekerasan Seksual di Wilayah Hukum Kota Jambi", Jurnal Ilmu Hukum, Vol. 7, No. 2, (2016).

https://repository.unja.ac.id/619/

Hafrida, H., \& Helmi, H. "Perlindungan Korban Melalui Kompensasi dalam Peradilan Pidana Anak". Jurnal Bina Mulia Hukum, (2020).

DOI: https://doi.org/10.23920/jbmh.v5i1.16

Rahmi, Elita dan Elly Sudarti. "State Protection Upon Adolescent Victim of Incest Rape Through Gender Lens”, Diponegoro Law Review. Vol. 04, No. 01, (2019).

DOI: https://doi.org/10.14710/dilrev.4.1.2019.89-104

\section{Internet}

"Bentuk UPTD PPA, Negara Tingkatkan Layanan Bagi Korban Kekerasan". https://www.kemenpppa.go.id/index.php/page/read/29/2352/bentukuptd-ppa-negara-tingkatkan-layanan-bagi-korban-kekerasan, diakses pada 21 Juli 2020 Pukul 13:48 WIB.

"Sejak 1 Januari 2019, P2TP2A Menjadi UPTD-PPA". https://www.inibalikpapan.com/sejak-1-januari-2019-p2tp2a-menjadiuptd-ppa/, diakses pada 21 Juli 2020 Pukul 13:48 WIB.

Institute for Criminal Justice Reform. "10 Tahun LPSK dalam Wajah Hukum Indonesia: Rekomendasi untuk Para Pimpinan Lembaga Perlindungan Saksi dan Korban (LPSK) yang Akan Terpilih". http://icjr.or.id/data/wpcontent/uploads/2018/10/RekomendasiPimpinan LPSK Final 18102018.pdf, diakses pada 13 April 2019 pukul 15.53 WIB.

Media Indonesia. https://mediaindonesia.com/read/detail/176523-putusan-pidanakorban-perkosaan-di-jambi-disoal, diakses pada 29 Februari 2019, pukul 16:07 WIB.

Siaran Pers Catatan Tahunan (CATAHU) Komnas Perempuan 2019, https://www.komnasperempuan.go.id/read-news-siaran-pers-catatantahunan-catahu-komnas-perempuan-2019, diakses pada 17 April 2019 pukul 19:23 WIB. 